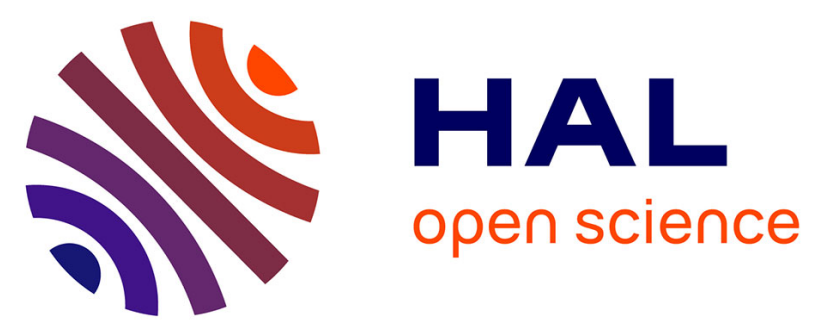

\title{
Block selective grafting of poly(vinylphosphonic acid) from aromatic multiblock copolymers for nanostructured electrolyte membranes
}

\author{
Arindam Sannigrahi, Shogo Takamuku, Patric Jannasch
}

\section{To cite this version:}

Arindam Sannigrahi, Shogo Takamuku, Patric Jannasch. Block selective grafting of poly(vinylphosphonic acid) from aromatic multiblock copolymers for nanostructured electrolyte membranes. Polymer Chemistry, 2013, pp.4207-4218. 10.1039/C3PY00513E . hal-00904742

HAL Id: hal-00904742

https://hal.science/hal-00904742

Submitted on 15 Nov 2013

HAL is a multi-disciplinary open access archive for the deposit and dissemination of scientific research documents, whether they are published or not. The documents may come from teaching and research institutions in France or abroad, or from public or private research centers.
L'archive ouverte pluridisciplinaire HAL, est destinée au dépôt et à la diffusion de documents scientifiques de niveau recherche, publiés ou non, émanant des établissements d'enseignement et de recherche français ou étrangers, des laboratoires publics ou privés. 


\title{
Block selective grafting of poly(vinylphosphonic acid) from aromatic multiblock copolymers for nanostructured electrolyte membranes
}

\author{
Arindam Sannigrahi, Shogo Takamuku and Patric Jannasch* \\ Department of Chemistry, Polymer \& Materials Chemistry, \\ Lund University, P.O.B. 124, SE-221 00 Lund, Sweden \\ *Corresponding author: e-mail patric.jannasch@chem.lu.se
}

Alternating aromatic multiblock copolymers have been structurally designed to enable selective lithiation and subsequent anionic graft polymerization from only one of the two block types. The multiblock copolymers were prepared by coupling polyfluoroether (PFE) and polysulfone (PSU) precursor blocks under mild conditions. The judicious combination of blocks allowed for block selective lithiation of the PSU blocks to obtain a macroinitiator for anionic polymerization of diethyl vinylphosphonate. The block selective grafting was confirmed by ${ }^{1} \mathrm{H}$ and ${ }^{19} \mathrm{~F}$ NMR spectroscopy. After hydrolysis to obtain poly(vinylphosphonic acid) (PVPA) side chains, mechanically stable transparent electrolyte membranes were cast from 1-methyl-2-pyrrolidinone solutions. Analysis by atom force microscopy showed that the copolymers self-assembled to form nanostructured membranes with continuous proton conducting PVPA phase domains. Calorimetry showed separate glass transition temperatures from the PFE and PVPA phases, with the latter increasing with increasing annealing temperatures as a result of anhydride formation. Fully hydrated multiblock copolymer membranes reached proton conductivities above $80 \mathrm{mS}$ $\mathrm{cm}^{-1}$ at $120^{\circ} \mathrm{C}$. The approach of block selective lithiation and modification of aromatic block copolymers can be used as a general strategy to prepare durable and functional nanostructured polymer membranes and materials.

Keywords: Block copolymers; Polyelectrolytes; Ionomers; Microphase separation; Water uptake; Proton conductivity; Fuel cell membranes. 


\section{Introduction}

Phosphonated polymers are acidic, capable of hydrogen bonding and have a strong affinity for a broad variety of inorganic surfaces and metal ions. Their properties open up for a wide range of different application areas including flame-retarding additives, ${ }^{1-2}$ anti-corrosion ${ }^{3}$ and antimicrobial coatings ${ }^{4}$, dental materials, ${ }^{5-6}$ thermoresponsive materials ${ }^{7}$, and materials for water purification and proton-exchange membranes. ${ }^{8-10}$ To this end, both fluorinated ${ }^{11-16}$ and nonfluorinated ${ }^{17-25}$ polymers have been functionalized with phosphonic acid and studied for different purposes. Poly(vinylphosphonic acid) (PVPA) in particular contains a very high concentration of phosphonic acid units directly attached to the polymer backbone. ${ }^{26-27}$ The polymer is water soluble and shows a strong polyelectrolyte effect with only one proton per $-\mathrm{PO}(\mathrm{OH})_{2}$ unit titratable. $^{9}$ Its very high ionic content enables the preparation of proton-exchange membranes with very high ion exchange capacities (IECs). PVPA thus shows high proton conductivity, although anhydride formation leading to P-O-P bridges seriously reduces the conductivity under low relative humidity and high temperature. ${ }^{11-13}$

Various block ${ }^{28,29}$ and graft $^{30-33}$ copolymers, inorganic composites ${ }^{34}$ as well as interpenetrating networks ${ }^{35}$, based on PVPA have been prepared to circumvent the issues of water solubility and studied as membranes for fuel cells. We have previously grafted PVPA from polysulfone $^{31}$ (PSU) and poly(phenylene oxide) ${ }^{32}$ (PPO) via anionic polymerisation. The former polymer was lithiated exclusively in positions ortho to the sulfone bridges using butyllithium, and used as polyfunctional macroinitiators for anionic polymerisation of diethyl vinylphosphonate. After hydrolysis and membrane casting, the PVPA grafted materials showed relatively high proton conductivity in the nominally dry and fully hydrated conditions in the range of 1-5 and 10-100 $\mathrm{mS} \mathrm{cm}^{-1}$, respectively. ${ }^{31,32}$ Very high IECs are needed to reach high proton conductivity at low water contents. However, this leads to excessive water uptake at high relative humidity which, in turn, causes swelling, dilution effects and compromises the mechanical stability of the membranes. The PVPA grafts in the PSU and PPO materials were randomly distributed along the polymer backbone, giving relatively short PSU segments inbetween the grafts. This leads to the formation of quite small and non-uniform glassy PSU phase domains in the membranes to stabilize the membrane morphology and limit the water uptake. One strategy to alleviate these issues is to only graft specific segments in the aromatic polymer, 
leaving larger aromatic segments to form large glassy phase domains to stabilize the membranes (Scheme 1). Retaining the "grafting from" approach, this would require an aromatic block copolymer structure where one segment type could be selectively lithiated and grafted. Aromatic multiblock copolymers have previously been prepared by coupling of chain-end functionalised precursor segments of, e.g., PSUs and polyketones formed by polycondensation via nucleophilic aromatic substitutions. ${ }^{36-40}$ However, nucleophilic aromatic substitutions require the presence of electron-withdrawing groups, such as ketone, sulfone, and nitrile, to activate the halide atoms for substitution. With the exception of sulfone groups, these are in general incompatible with the lithiation reaction.

In the present work we have prepared multiblock copolymers by coupling PSU and polyfluoroether (PFE) precursor blocks. The latter block was prepared by polycondensation of hexafluorobenzene and bisphenol $\mathrm{P}$ to give a block structure where all the residual fluorine atoms were deactivated for substitution by their location in ortho positions to ether bridges. Accordingly, we hypothesised that this specific PFE block would remain unaffected during the addition of butyllithium. The PSU blocks of the carefully designed multiblock copolymers were selectively lithiated and grafted with diethyl vinylphosphonate. The ester functions of the grafted multiblock copolymers were hydrolysed and membranes based on the PVPA containing multiblock copolymers were evaluated by thermal analysis, microscopy, and water uptake and proton conductivity measurements to evaluate their use as electrolyte materials.

\section{Experimental}

\subsection{Materials}

4,4'-(1,4-Phenylenediisopropylidene)bisphenol (Bisphenol P, Sigma-Aldrich, 99\%) and 4,4'dichlorodiphenylsulfone (DCDPS, Acros, 97\%) were recrystallized from toluene and dried in vacuum oven at $80{ }^{\circ} \mathrm{C}$ before use. Resorcinol (RS, Acros, 98\%), hexafluorobenzene (Aldrich, 99\%), n-butyl lithium (BuLi, in hexanes, Acros, $2.5 \mathrm{M}$ ), 1-methyl-2-pyrrolidinone (NMP, Acros, 99\%), $N, N$-dimethylacetamide (DMAc, Acros, 99\%), dimethylsulfoxide (DMSO, Acros, 99.9\%), 2-propanol (Honeywell, 98\%), n-hexane (Scharlau, 96\%), methanol (Honeywell, 98\%), toluene (Fisher Scientific, HPLC grade), 1,1-diphenylethylene (DPE, Aldrich, 99\%), diethyl vinylphosphonate (DEVP, Aldrich, 97\%) and hydrochloric acid (Honeywell, 37\%) were used as 
received. $\mathrm{K}_{2} \mathrm{CO}_{3}$ (Acros, 99\%) was dried at $120{ }^{\circ} \mathrm{C}$ and tetrahydrofuran (THF, Fisher Scientific, Analytical reagent grade) was dried with $5 \mathrm{wt} \%$ molecular sieves (Acros, $4 \AA$, 8-12 mesh) before use. The molecular sieves were activated at $250{ }^{\circ} \mathrm{C}$ for $48 \mathrm{~h}$ in an oven and subsequently cooled to room temperature under vacuum.

\subsection{Synthesis of PSU precursor blocks}

The PSU precursor block was prepared according to Scheme 2. Hydroxy terminated oligomers were first synthesised as follows. DCDPS (13.2797 g, $46.245 \mathrm{mmol}), \mathrm{RS}(5.5166 \mathrm{~g}, 50.101$ $\mathrm{mmol}), \mathrm{K}_{2} \mathrm{CO}_{3}(7.67 \mathrm{~g}, 55.5 \mathrm{mmol})$ and DMAc $(75 \mathrm{~mL})$ were added to a two-neck flask (250 $\mathrm{mL}$ ) equipped with a magnetic stirrer, a $\mathrm{N}_{2}$ inlet and a condenser fitted with a $\mathrm{CaCl}_{2}$ filter. The mixture was initially heated at $160{ }^{\circ} \mathrm{C}$ for $4 \mathrm{~h}$ and then at $175^{\circ} \mathrm{C}$ for $24 \mathrm{~h}$. A very low flow of $\mathrm{N}_{2}$ was maintained throughout the polycondensation reaction. Finally, the product was precipitated in deionized water and washed several times with deionized water. The precipitate was filtered and dried under vacuum at $30{ }^{\circ} \mathrm{C}$ for $24 \mathrm{~h}$ (overall yield: 94\%). The molecular weight was determined to be $M_{\mathrm{n}}=3.8 \mathrm{kDa}$ using ${ }^{1} \mathrm{H}$ NMR data recorded with a $\mathrm{CDCl}_{3}$ solution.

Reactive end groups were obtained by capping the PSU oligomer with hexafluorobenzene in NMP at $80{ }^{\circ} \mathrm{C}$. In a $100 \mathrm{~mL}$ two neck flask, $7.00 \mathrm{~g}$ oligomer $(1.81 \mathrm{mmol})$ was added together with $\mathrm{K}_{2} \mathrm{CO}_{3}(2.45 \mathrm{~g}, 18.1 \mathrm{mmol})$, hexafluorobenzene $(4.18 \mathrm{~mL}, 36.2 \mathrm{mmol})$ and NMP $(50 \mathrm{~mL})$. The mixture was kept at $80{ }^{\circ} \mathrm{C}$ for $24 \mathrm{~h}$, before precipitating the product in 2propanol. The product was carefully washed with deionized water and dried in a vacuum oven at $30{ }^{\circ} \mathrm{C}$ for $24 \mathrm{~h}$ (overall yield: $87 \%$ ). This sample was designated PSU4.

\subsection{Synthesis of PFE precursor blocks}

Two hydroxyl terminated PFE precursor blocks with different molecular weights were prepared by a polycondensation (Scheme 2) in a three-neck $100 \mathrm{~mL}$ flask equipped with a magnetic stirrer, a Dean-Stark trap filled with toluene, a $\mathrm{N}_{2}$ inlet, and a condenser fitted with a $\mathrm{CaCl}_{2}$ filter. Bisphenol P (5.7689 g, $16.6505 \mathrm{mmol})$ and $\mathrm{K}_{2} \mathrm{CO}_{3}(2.69 \mathrm{~g}, 19.5 \mathrm{mmol})$ were first heated in DMAc at $110{ }^{\circ} \mathrm{C}$ for $3 \mathrm{~h}$ for dehydration during azeotropic removal of the toluene. The mixture was then cooled to $30^{\circ} \mathrm{C}$ before adding hexafluorobenzene $(1.87 \mathrm{~mL}, 16.24 \mathrm{mmol})$. The reaction temperature was kept at $50{ }^{\circ} \mathrm{C}$ for $3 \mathrm{~h}$ and then at $80{ }^{\circ} \mathrm{C}$ overnight. The $\mathrm{N}_{2}$ purging was stopped 
after adding the hexafluorobenzene. The oligomer was precipitated in methanol and washed with deionized water. It was filtered and dried in a vacuum oven at $30{ }^{\circ} \mathrm{C}$ for $24 \mathrm{~h}$ (overall yield: 94\%). The molecular weights of the two hydroxy terminated PFE precursor blocks were determined to be $M_{\mathrm{n}}=6.1$ and $8.0 \mathrm{kDa}$ from ${ }^{1} \mathrm{H}$ NMR data recorded with a $\mathrm{CDCl}_{3}$ solution. These samples were designated PFE6 and PFE8, respectively.

\subsection{Synthesis of PFE-PSU multiblock copolymers}

Two alternating multiblock copolymers were synthesised by coupling of the two PFE precursor blocks (PFE6 and PFE8, respectively) with the PSU4 precursor block in NMP at $80{ }^{\circ} \mathrm{C}$ during 4 h (Scheme 2). The two copolymers were designated PFEx-PSU4 where $x$ is either 6 or 8 for the two PFE precursor blocks. As an example, block copolymer PFE8-PSU4 was synthesised as follows. PFE8 (8.0 kDa, $2.6959 \mathrm{~g}, 0.337 \mathrm{mmol})$ and PSU4 precursor block (3.8 kDa, $1.30 \mathrm{~g}$, $0.337 \mathrm{mmol}), \mathrm{K}_{2} \mathrm{CO}_{3}(0.056 \mathrm{~g}, 0.404 \mathrm{mmol})$ and NMP $(22 \mathrm{~mL})$ were added to a $100 \mathrm{~mL}$ threeneck flask equipped with a magnetic stirrer, a $\mathrm{N}_{2}$ inlet, and a condenser fitted with a $\mathrm{CaCl}_{2}$ filter. The mixture was heated to $80{ }^{\circ} \mathrm{C}$ under $\mathrm{N}_{2}$ flow. After $4 \mathrm{~h}$ the mixture became viscous. The multiblock copolymer was precipitated in 2-propanol and washed with deionized water. It was then filtered out and dried in a vacuum oven at $30{ }^{\circ} \mathrm{C}$ for $24 \mathrm{~h}$ (overall yield: $93 \%$ ).

\subsection{Block selective grafting of PVPA}

The PSU blocks of the multiblock copolymers were selectively lithiated and grafted with PVPA via anionic polymerisation of DEVP as shown in Scheme 3. The grafted multiblock copolymers were designated PFExPSU4-g-PVPA $y$ where $y$ is the content of PVPA in wt $\%$. As an example, PFE8PSU4-g-PVPA57 was synthesised as follows. An amount of $0.500 \mathrm{~g}$ (0.456 mmol) multiblock copolymer PFE8PSU4 was dissolved in $100 \mathrm{~mL}$ of anhydrous THF in a round bottom glass reactor fitted with a gas inlet and outlet, a thermometer, and a rubber septum. The solution was cooled to $-70{ }^{\circ} \mathrm{C}$ and degassed several times. Next, the required amount of $n$-BuLi $(0.2 \mathrm{~mL}$, $0.456 \mathrm{mmol}$ ) was added dropwise to form a yellow-orange solution. After $15 \mathrm{~min}$, DPE ( $25 \mu \mathrm{L}$, $0.228 \mathrm{mmol}$ ) was added. After leaving the reaction for $10 \mathrm{~min}$, the required amount of DEVP $(0.35 \mathrm{~mL}, 2.28 \mathrm{mmol})$ was added all at once by syringe, and the polymerization was left to proceed for $5 \mathrm{~h}$ at $-70^{\circ} \mathrm{C}$. At the addition of the DEVP monomer the solution turned opaque and violet and the viscosity increased. The grafted multiblock copolymer was precipitated in $200 \mathrm{~mL}$ 
of hexane and the yellow-white precipitate was filtered off and washed several times with distilled water. Finally, the copolymer was dried under vacuum during $24 \mathrm{~h}$ at $30{ }^{\circ} \mathrm{C}$. The copolymer in the ester form was converted into the acid form in $37 \%$ aq. hydrochloric acid. In a typical reaction, $0.5 \mathrm{~g}$ of copolymer in the ester form was placed in $25 \mathrm{~mL}$ of the hydrochloric acid. After $24 \mathrm{~h}$ of reflux, the copolymer was filtered off and carefully washed with water. The copolymer was finally dried under vacuum for $24 \mathrm{~h}$ at $60^{\circ} \mathrm{C}$.

\subsection{Polymer characterization}

Size exclusion chromatography (SEC) was used to determine the molecular weight of the precursor blocks and the PFEx-PSU4 multiblock copolymers. All samples were analyzed on a Viscotek GPCmax VE-2001 equipped with ViscotekTriSEC Model 302 triple detector using two PLgel mixed-D columns from Polymer Laboratories with chloroform at an elution rate of $1 \mathrm{~mL}$ $\min ^{-1}$ at room temperature. Calibration was done using polystyrene standards. ${ }^{1} \mathrm{H},{ }^{19} \mathrm{~F}$, and ${ }^{31} \mathrm{P}$ NMR data were recorded using a Bruker DRX 400 spectrometer. All the spectra were recorded in $\mathrm{CDCl}_{3}$ and DMSO- $d_{6}$ solvents at room temperature. The ratio between the integrated peak of the $\mathrm{CH}_{2}$ protons of the phosphonic ester at $\delta=4.1 \mathrm{ppm}$ and the integrated peaks of the aromatic protons of the main chain between $\delta=6.8-8.1 \mathrm{ppm}$ was used in the calculations of the PVPA content and the theoretical ion exchange capacity (IEC) of the hydrolyzed copolymers (Table 2). ${ }^{31}$ In the phosphonic acid units of the PVPA side chains act as monoprotic acids, ${ }^{26,31}$ and thus the theoretical IEC is defined as mmol $\mathrm{P}$ per $\mathrm{g}$ protonated membrane. FTIR spectra were recorded on a Bruker IFS 66 FT-IR spectrometer between 400 and $4000 \mathrm{~cm}^{-1}$ at a resolution of 4 $\mathrm{cm}^{-1}$ using 128 scans. The polymers were ground together with $\mathrm{KBr}$ before sample tablets were pressed.

\subsection{Thermal analysis}

Thermogravimetric analysis (TGA) was carried out on a Q500 TGA analyzer from TA instruments. The thermal stability of the polymers was measured under nitrogen and air,

respectively, up to $600{ }^{\circ} \mathrm{C}$ at a scan rate of 10 and $1{ }^{\circ} \mathrm{C} \mathrm{min}{ }^{-1}$, respectively. Initially the samples were kept at $150{ }^{\circ} \mathrm{C}$ isothermally for $10 \mathrm{~min}$ to remove potential water and solvent residues. Differential scanning calorimetry (DSC) was performed using a TA Instruments Q1000 DSC to 
determine the glass transition temperatures $\left(T_{\mathrm{g}} \mathrm{s}\right)$ for all the precursors and multiblock copolymers. Samples were first heated from 50 to $300{ }^{\circ} \mathrm{C}$ and then cooled to $50{ }^{\circ} \mathrm{C}$ and finally heated to $300{ }^{\circ} \mathrm{C}$ at $10^{\circ} \mathrm{C} \mathrm{min}^{-1}$. The reported $T_{\mathrm{g}} \mathrm{s}$ were determined from the second heating scan. The PFExPSU4-g-PVPAy copolymers were analyzed using the following sequence of heating scans at a rate of $20{ }^{\circ} \mathrm{C} \mathrm{min}-1: 0 \rightarrow 150 \rightarrow 0 \rightarrow 200 \rightarrow 0 \rightarrow 250 \rightarrow 0 \rightarrow 300{ }^{\circ} \mathrm{C}$. In-between the heating scans the samples were cooled at a rate of $30{ }^{\circ} \mathrm{C} \mathrm{min}$. The $T_{\mathrm{g}} \mathrm{s}$ were evaluated from the data recorded during heating scan by identifying the inflection points.

\subsection{Microscopy}

The surface morphologies of the grafted copolymers were investigated by Atom Force Microscopy (AFM) in tapping mode using an XE-100 Park system. Topology and phase images were recorded at a scanning frequency of $1 \mathrm{~Hz}$. No image processing was done.

\subsection{Membrane preparation}

The required amount of PFExPSU4- $g$-PVPAy copolymer in the acid form was dissolved (5 wt $\%$ ) in NMP at $100{ }^{\circ} \mathrm{C}$. Membranes were then cast in Petri dishes at $100{ }^{\circ} \mathrm{C}$ under a continuous nitrogen flow during $24 \mathrm{~h}$. The transparent and slightly yellow membranes were detached from the Petri dishes after immersion in deionized water. To remove impurities or possible solvent residues from the membranes, they were first boiled and washed several times in deionized water and then dried under vacuum at $30^{\circ} \mathrm{C}$ for $24 \mathrm{~h}$.

\subsection{Water uptake measurements}

The membranes were first thoroughly dried under vacuum for $24 \mathrm{~h}$ at $30^{\circ} \mathrm{C}$ before measuring the weight of the dry membranes. Next, the membranes were immersed in deionized water for two days at room temperature. The surface water of the wet membranes was quickly wiped off with tissue paper before measuring the weight of the wet membranes. The water uptake $\left(W_{\text {water }}\right)$ was then calculated as:

$$
W_{\text {water }}=\frac{W_{w e t}-W_{d r y}}{W_{d r y}} \times 100 \%
$$


where $W_{\text {wet }}$ and $W_{\text {dry }}$ were the weights of the wet and dry membranes, respectively. Similarly, the temperature dependent water uptake was investigated from 20 to $100{ }^{\circ} \mathrm{C}$ under immersed conditions.

\subsection{Proton conductivity measurements}

The proton conductivity was measured by electrochemical impedance spectroscopy (EIS) using a Novocontrol high-resolution dielectric analyzer V $1.01 \mathrm{~S}$ equipped with a Novocontrol temperature system. The proton conductivity $\left(\mathrm{S} \mathrm{cm}^{-1}\right)$ of the membranes was measured between 20 and $120^{\circ} \mathrm{C}$ under fully hydrated conditions over the frequency range of $10^{-1}-10^{7} \mathrm{~Hz}$ at $50 \mathrm{mV}$ amplitude in a two-probe cell. The data was analyzed using the software WinDeta from Novocontrol to evaluate the proton conductivity.

\section{Results and discussions}

\subsection{Multiblock copolymer synthesis}

We have previously successfully grafted PSU homopolymers with PVPA side chains to prepare highly proton conducting polymers and membranes. ${ }^{31}$ PSU is exclusively lithiated in the aromatic ortho positions of the sulfone bridges and thus forms an efficient macroinitiator for anionic polymerization after reaction with DPE. In the present study, our aim was to identify and synthesize multiblock copolymers with a combination of blocks that would enable one of the block types to be selectively lithiated and grafted without affecting the other block type. To that end, two different multiblock copolymers having PFE and PSU blocks were prepared by coupling of precursor blocks under mild conditions to avoid branching and other side-reactions (Scheme 2). We assumed that the PFE under suitable conditions would be left unmodified during the lithiation and the subsequent anionic polymerisation. The PFE precursor blocks were prepared by polycondensations of bisphenol $\mathrm{P}$ and hexafluorobenzene, and the PSU precursor block were prepared from DCDPS and RS. The slight excess of bisphenol P and RS, respectively, were employed in the reactions to ensure that the precursors were terminated by hydroxyl groups and that the predetermined molecular weights were reached. The PSU precursor was quantitatively end capped with hexafluorobenzene to enable efficient coupling reactions.

Hexafluorobenzene and bisphenol $\mathrm{P}$ were chosen for the hydrophobic PFE block in order to avoid any reaction with BuLi during the lithiation reaction and to favor solubility in THF, the 
preferred solvent during the lithiation. We hypothesized that the position of the fluorine atoms ortho to the ether bridges in the PFE would efficiently deactivate any nucleophilic substitution reactions potentially caused by the lithiated species. Concurrently, DCDPS and RS were selected for the PSU block in order to have a high density of diaryl sulfone sites for lithiation. Moreover, the meta configuration induced by RS facilitates solubility in THF. In all cases, the polycondensations gave hydroxyl terminated precursor blocks with well-controlled molecular weights and solubility in THF.

Two different PFExPSU4 multiblock copolymers were prepared by varying the PFE block length (6.1 and $8.0 \mathrm{kDa})$, keeping the PSU block length constant and smaller (3.8 $\mathrm{kDa})$. All the precursor blocks and the PFExPSU4 multiblock copolymers were characterized by ${ }^{1} \mathrm{H}$ NMR, SEC, DSC and TGA, and the data are collected in Table 1. Representative ${ }^{1} \mathrm{H}$ NMR spectra are shown in Fig. 1 and confirmed the structure of the respective samples. The integrals of the shifts originating from protons $\boldsymbol{a}$ and $\boldsymbol{c}^{\prime}$ were used to calculate the molecular weight of the PSU precursor block (Fig. 1a), and the integrals of the signals from protons $\boldsymbol{g}$ and $\boldsymbol{f}$ ' were used to calculate the molecular weights of the PFE precursor blocks (Fig. 1b).

By DSC analysis it was found that the $T_{\mathrm{g}}$ of the PFE precursor blocks increased with molecular weight (Table 1), as expected. Each of the two multiblock copolymers showed two $T_{\mathrm{g}} \mathrm{S}$ to indicate microphase separation of the PFE and PSU blocks (Fig. 2). The $T_{\mathrm{g} 1}$ of the PFE phase was approximately $10{ }^{\circ} \mathrm{C}$ higher than the respective neat precursor block, and the $T_{\mathrm{g} 2}$ of the PSU phase was approximately the same as for the neat PSU precursor block. This may indicate a partial mixing of the PSU blocks in the PFE phase domain, and/or that the PFE chain segments were considerably constrained by the connectivity with the PSU blocks after the DSC cooling scan.

\subsection{Selective grafting of multiblock copolymers}

The PFExPSU4 multiblock copolymers were used as macroinitiators for anionic graft polymerization of DEVP (Scheme 3). The aim was to selectively and densely graft the PSU blocks with PVPA side chains to obtain multiblock copolymers having continuous phases with very high local concentrations of proton conducting phosphonic acid groups. After lithiation of the multiblock copolymers, DPE was added to form the active initiator sites for the polymerization of DEVP at $-70{ }^{\circ} \mathrm{C}$. We have previously used the same strategy to polymerize 
DEVP to prepare block ${ }^{28}$ and graft ${ }^{31,32}$ copolymers. After the polymerizations, the ester functions were hydrolyzed by reflux in aq. $\mathrm{HCl}$. In this way, five different grafted multiblock copolymers were made with PVPA contents ranging from 57 to $82 \mathrm{wt} \%$ (Table 2). The phosphonated copolymers in both the ester and the acid forms were characterised by ${ }^{1} \mathrm{H},{ }^{19} \mathrm{~F},{ }^{31} \mathrm{P}$ NMR and IR spectroscopy. Before hydrolysis, the signals of the $\mathrm{CH}_{2}$ and $\mathrm{CH}_{3}$ protons of the phosphonic ester were found by ${ }^{1} \mathrm{H}$ NMR at $\delta=4.1 \mathrm{ppm}$ and at $\delta=1.2 \mathrm{ppm}$, assigned as $\boldsymbol{b}$ and $\boldsymbol{a}$, respectively, in Fig. 3a. The $\mathrm{CH}$ and $\mathrm{CH}_{2}$ protons from the poly(diethyl vinylphosphonate) chains were confirmed by the presence of two broad signals between $\delta=1.3-1.7$ ppm (see Fig. 3a).

One of the crucial points of the present work was to selectively graft the PSU blocks with PVPA without affecting the PFE blocks. BuLi is very reactive and there is a risk that the fluorine atoms of the PFE block may be substituted in connection with the grafting reactions. In order to ensure that the lithiation and the subsequent grafting were selective, we analyzed the copolymers before and after grafting by ${ }^{19} \mathrm{~F}$ NMR spectroscopy. As expected, the solubility greatly changed after the grafting which complicated the analysis. The hydrophobic PFExPSU4 copolymers were readily soluble in $\mathrm{CDCl}_{3}$, while the hydrophilic PFExPSU4-g-PVPAy copolymers in the ester form easily dissolved in DMSO- $d_{6}$. The former copolymers just barely dissolved in DMSO- $d_{6}$ after ultrasonication and heating at $100{ }^{\circ} \mathrm{C}$ for $2 \mathrm{~h}$. Fig. 4 a shows the expected single sharp signal at $\delta=-154.3 \mathrm{ppm}$ from the PFExPSU4 copolymers in $\mathrm{CDCl}_{3}$ to indicate that all the fluorine atoms were chemically equivalent. The same sample shows a much broader asymmetrical signal at $\delta=-155.3 \mathrm{ppm}$ in DMSO- $d_{6}$, most probably because of the limited solubility (Fig. $4 \mathrm{~b}$ ). After grafting, the spectra recorded in DMSO- $d_{6}$ showed a single symmetrical rather broad signal at $\delta$ $=-155.3 \mathrm{ppm}$, again indicating that all the fluorine atoms were equivalent (Fig. 4c). Thus, the fluorine signal was not shifted after the grafting which indicated that PFE was not affected by the grafting reactions. In addition, multiple signals in the ${ }^{19} \mathrm{~F}$ NMR spectra would be expected if some of the fluorine atoms had been displaced. We concluded that the PSU blocks were selectively lithiated and grafted while the PFE blocks were left unmodified. In this context it should be mentioned that a corresponding multiblock copolymer having PFE blocks based on decafluorobiphenyl, instead of hexafluorobenzene, was not possible to lithiate selectively under the same conditions and multiple signals were found in the ${ }^{19} \mathrm{~F}$ NMR spectrum. In contrast to the PFE blocks based on hexafluorobenzene, all the fluorine atoms in PFE blocks based on 
decafluorobiphenyl are not placed ortho to ether bridges, and are thus not deactivated for nucleophilic substitution during the lithiation.

The quantitative hydrolysis of the diethyl phosphonate ester groups was indicated by the disappearance of the characteristic signals of the phosphonic ester in the ${ }^{1} \mathrm{H}$ NMR spectra of the hydrolyzed products (Fig. 3c). Based on this result, it was possible to calculate the IEC from the spectra and these IEC values are collected in Table 2 for all five grafted multiblock copolymers. In comparison with the ${ }^{31} \mathrm{P}$ NMR signal arising from the diethyl ester derivatives at $\delta=32.9 \mathrm{ppm}$ (Fig. 3b), the hydrolyzed copolymers showed a slightly lower chemical shift at $\delta=29.2 \mathrm{ppm}$ (Fig. 3d). The latter shift was attributed to the diacid form of the phosphonate units. ${ }^{31}$ In some cases a small signal at $\delta=21 \mathrm{ppm}$ was observed in the ${ }^{31} \mathrm{P}$ NMR spectra of the hydrolyzed copolymers. This signal confirmed the presence of anhydrides produced through condensation of the phosphonic acid groups to form P-O-P bonds.

Representative FTIR spectra of the PFExPSU4 multiblock copolymers and the PFExPSU4-g-PVPAy multiblock copolymers in both the ester and acid forms are presented in Fig. 5. Before analysis, the PFExPSU4-g-PVPAy multiblock copolymers were dried in a vacuum oven at $30^{\circ} \mathrm{C}$ overnight to remove traces of water. The $\mathrm{P}=\mathrm{O}$ stretching is usually found to absorb at $1320-1200 \mathrm{~cm}^{-1}{ }^{31}$ The FTIR spectrum of the grafted copolymer in the ester form (Fig. 5b) showed four new bands in comparison with those identified in the spectrum of the ungrafted copolymer in Fig. 5a. The bands at 1052 and $1023 \mathrm{~cm}^{-1}$, as well as the band at $778 \mathrm{~cm}^{-1}$, were assigned to (P)-O-C absorptions of the ester group, and the band at $952 \mathrm{~cm}^{-1}$ was ascribed to $\mathrm{P}$ $\mathrm{O}-(\mathrm{C})$ vibrations. As shown in Fig. 5c, these bands disappeared after hydrolysis, and the (P)-O-H bending vibration at $990 \mathrm{~cm}^{-1}$ and a broad (P)-O-H stretching band at $2300 \mathrm{~cm}^{-1}$ appeared for the acidic copolymers (not shown). Thus, the FTIR spectra confirmed the successful hydrolysis of the phosphonate ester groups.

\subsection{Thermal properties}

The thermal stability of all the multiblock copolymers was analyzed up to $600{ }^{\circ} \mathrm{C}$ under nitrogen at a heating rate of $10^{\circ} \mathrm{C} \mathrm{min}^{-1}$, as well as under air at $1{ }^{\circ} \mathrm{C} \mathrm{min}^{-1}$. Fig. 6a shows representative TGA curves of a PFE-PSU multiblock copolymer and grafted copolymers derived from this 
copolymer in the ester and acid form. The ungrafted multiblock copolymers showed decomposition temperatures $\left(T_{\mathrm{d}} \mathrm{S}\right)$ at approx. $450{ }^{\circ} \mathrm{C}$. All the grafted copolymers in the ester form initially lost weight because of absorbed water. The first degradation step began at around $250{ }^{\circ} \mathrm{C}$ and was due to the decomposition of the ester groups by the formation and loss of ethylene. The magnitude of the weight loss was directly proportional to the PDEVP content of the samples, as previously noted for other copolymers. ${ }^{31,41}$ The second main degradation step between 400 and $500{ }^{\circ} \mathrm{C}$ was assigned for the cleavage of the $\mathrm{C}-\mathrm{P}$ bond and degradation of the PVPA chain. ${ }^{18}$ For all the grafted copolymers in the acid form, an initial weight loss was observed above $150{ }^{\circ} \mathrm{C}$ attributed to the loss of water and formation of $\mathrm{P}-\mathrm{O}-\mathrm{P}$ anhydride bonds. This was in accordance with previous findings. ${ }^{26,27,31,32}$

Fig. $6 \mathrm{~b}$ shows the TGA curves of the grafted multiblock copolymers with different PVPA contents ranging from 57 to $82 \mathrm{wt} \%$ under air at $1^{\circ} \mathrm{C} \mathrm{min}{ }^{-1}$. The initial weight loss (less than $1 \%$ ) above $150{ }^{\circ} \mathrm{C}$ was assigned to the reversible condensation of the phosphonic acid, as discussed already. The small weight increases observed above $300{ }^{\circ} \mathrm{C}$ are most probably due to oxygen uptake in connection with the formation of phosphates as the phosphonic acid is degraded, and has been reported previously. ${ }^{31,32}$ The main degradation step was noted above 350 ${ }^{\circ} \mathrm{C}$ for all PFExPSU4-g-PVPAy samples and was attributed to the degradation of PVPA side chains. From Fig. $6 \mathrm{~b}$, it is clearly visible that the magnitude of the weight loss above $350{ }^{\circ} \mathrm{C}$ decreased with increasing PVPA content, which is mainly attributed to the flame-retardant property of the phosphonic acid. ${ }^{42}$ The $T_{\mathrm{d}} \mathrm{S}$ for all the PFExPSU4-g-PVPAy copolymer samples in the acid form are collected in the Table 3.

All the multiblock polymer samples were analyzed by DSC to evaluate the glass transitions. Block copolymers having two immiscible amorphous blocks usually microphase separate and show two separate glass transitions. As mentioned previously, the PFE6PSU4 and PFE8PSU4 copolymers displayed two glass transitions to indicate phase separation between the blocks (Fig. 2). The grafted copolymers in the acid form showed two glass transition temperatures, one at $T_{\mathrm{g}}=131{ }^{\circ} \mathrm{C}$ from the PFE block and the other $T_{\mathrm{g}}$ was found to increase with increasing annealing temperature during a temperature cycling with successively higher temperatures, as shown in Fig. 7. This glass transition originated from the PVPA phase for which the $T_{\mathrm{g}}$ increased because of an increased level of anhydride formation with the temperature. The 
anhydride formation leads to intra- and intermolecular crosslinks which decreases the segmental mobility of the PVPA side chains leading to increased values of $T_{\mathrm{g}} \cdot{ }^{26-28,32}$ As expected, no glass transition from the PSU phase was detected for the acidic copolymers because of the dense grafting with PVPA.

\subsection{Multiblock copolymer membrane morphology}

PVPA grafted multiblock copolymer membranes were cast in the acid form from NMP solutions

at $100{ }^{\circ} \mathrm{C}$. The morphologies of the membrane surfaces that faced the air during the casting were analyzed by tapping mode AFM analysis. Fig. 8 shows phase and topography images of two membranes. It is evident from the images that the grafted multiblock copolymers were distinctly phase separated and nanostructured. The soft PVPA phase domains appear as dark areas while the hard hydrophobic phases appear as the brighter areas in the images. From Fig. 8 it is seen that the PVPA phase domain seemed to be continuous and that the size of the PVPA phase domain increased with the PVPA content, as expected. The size of the PVPA phase domains was estimated to be in the range between 10 to $20 \mathrm{~nm}$ for copolymer PFE8PSU4-g-PVPA82.

\subsection{Water uptake and proton conductivity}

The water uptake is a very important parameter that determines both the mechanical properties and the level and mechanism of the proton conductivity in both sulfonated and phosphonated membranes. Typically, sulfonated membranes absorb more water molecules per acid group compared to phosphonated membranes, allowing higher IECs of the latter membranes to be used. Membranes based on the PFE6PSU4-g-PVPA75 and PFE8PSU4-g-PVPA82 copolymers were not stable in water at room temperature because of their high IEC, 6.9 and $7.7 \mathrm{mmol} \mathrm{P} \mathrm{g}^{-1}$, respectively. Fig. 9a shows the variation of the water uptake and $\lambda$ value between 20 and $100{ }^{\circ} \mathrm{C}$ for the other phosphonated membranes in the acid form. As expected, the water uptake increased with the temperature and the IEC value. At $20{ }^{\circ} \mathrm{C}$, the water uptake of PFE6PSU4-g-PVPA68 was $75 \mathrm{wt} \%$ but increased excessively to $176 \mathrm{wt} \%$ at $100{ }^{\circ} \mathrm{C}$. Membrane PFE8PSU4-g-PVPA57 showed a moderate increase of the water uptake with temperature and reached a value of $95 \%$ at $100{ }^{\circ} \mathrm{C}$. Membranes PFE8PSU4- $g$-PVPA57 and PFE8PSU4-g-PVPA59 had a very similar 
structure and PVPA content and both absorbed $45 \%$ water at $20{ }^{\circ} \mathrm{C}$. However, at $100{ }^{\circ} \mathrm{C}$ the latter membrane absorbed approximately 50\% more water than the former membrane. The water uptake of the phosphonated membrane corresponded to $\lambda=10-16$ water molecules per phosphonic acid unit at $100{ }^{\circ} \mathrm{C}$ (Fig. 9b). This can be compared to $\lambda=27$ for Nafion ${ }^{\circledR}$ NRE212. In comparison, a previously studied PSU with randomly placed PVPA grafts along the backbone, containing $57 \mathrm{wt} \%$ PVPA (IEC=5.3 mmol g $\mathrm{g}^{-1}$ ), took up $125 \mathrm{wt} \%$ water under immersed conditions at $20^{\circ} \mathrm{C} .{ }^{31}$ Moreover, a poly(phenylene oxide) randomly grafted with PVPA (65 wt $\%$ PVPA, IEC $=6.0 \mathrm{mmol} \mathrm{g}^{-1}$ ) had a water uptake of $111 \mathrm{wt} \%$ at $100 \% \mathrm{RH}$ and $25{ }^{\circ} \mathrm{C}^{32}$ This is considerably more than for the present grafted multiblock copolymer membranes with similar PVPA content. Consequently, the grafted block copolymer architecture provides morphologies which restrict the water uptake much more efficiently than randomly grafted copolymers.

The proton conductivity of the phosphonated membranes was measured from $-20{ }^{\circ} \mathrm{C}$ to $120{ }^{\circ} \mathrm{C}$ under fully hydrated conditions in water (Fig. 10). In order to remove possible impurities and/or residual solvent, the membranes were first boiled in deionized water, and then washed several times with deionized water before being dried under vacuum at $30{ }^{\circ} \mathrm{C}$ for $24 \mathrm{~h}$. The membranes were finally immersed in deionized water before the conductivity measurements. As seen in Fig. 10, the conductivity of Nafion ${ }^{\circledR}$ NRE212 increased sharply between -20 and $0{ }^{\circ} \mathrm{C}$ because of the melting of the absorbed water and reached high values at higher temperatures. At $-20{ }^{\circ} \mathrm{C}$, the conductivity of the phosphonated membranes exceeded that of the Nafion membrane. For the phosphonated membranes, the conductivity increased less sharply than Nafion between 20 and $20{ }^{\circ} \mathrm{C}$. The level of conductivity then followed the same trend as the water uptake. Consequently, membrane PFE6PSU4-g-PVPA68 showed the highest conductivity and reached $85 \mathrm{mS} \mathrm{cm}^{-1}$ at $120^{\circ} \mathrm{C}$. The previously studied PSU with randomly placed PVPA grafts (57 wt\% PVPA, IEC $=5.3 \mathrm{mmol} \mathrm{g}^{-1}$ ) showed a conductivity of $79 \mathrm{mS} \mathrm{cm}^{-1}$ under fully hydrated conditions at $120{ }^{\circ} \mathrm{C}^{31}$, while the poly(phenylene oxide) randomly grafted with PVPA (65 wt\% PVPA, IEC $=6.0 \mathrm{mmol} \mathrm{g}^{-1}$ ) showed $78 \mathrm{mS} \mathrm{cm}^{-1}$ under the same conditions. ${ }^{32}$ Thus, the grafted multiblock copolymers exceeded the proton conductivity of the randomly grafted polymers at a significantly lower water content. 


\section{Conclusions}

In the present work, we have selectively lithiated the PSU blocks of PFE-PSU multiblock copolymers without affecting the PFE blocks. The multiblock copolymers were then used as macroinitiators for anionic graft polymerization of DEVP from the lithiated PSU blocks. The block selective grafting was made possible because of the careful choice of the PFE block. By using of hexafluorobenzene as the dihalide monomer in the polycondensation, all the fluorine atoms of the resulting tetrafluorobenzene rings in the PFE were deactiviated for substitution because of the position ortho to the ether bridges to the bisphenol residues. This allowed for an efficient lithiation of the PSU block without affecting the PFE block. After hydrolysis of the DEVP monomer residues to obtain PVPA grafts, the multiblock copolymers showed phase separation with separate $T_{\mathrm{g}} \mathrm{s}$ of the PFE blocks and the PVPA grafts, respectively. Moreover, AFM showed that the membranes derived from the grafted copolymers were nanostructured with seemingly continuous PVPA phase domains. The membranes had high thermal stability and reached high proton conductivity. At an IEC of $6.3 \mathrm{mmol} \mathrm{P} \mathrm{g}^{-1}$ the membranes reached a conductivity of $85 \mathrm{mS} \mathrm{cm}$ cm $^{-1}$ under fully hydrated conditions. In comparison to the previous studies of PSU and PPO grafted with PVPA, the current grafted multiblock copolymers reached similar proton conductivity, but at a significantly lower water content. This is an advantage for their use as electrolyte membranes. The tendency of PVPA to form anhydrides was found to increase with the temperature, which is still an issue under hot and dry conditions. In light of the numerous possibilities to introduce functional groups via lithiation chemistry, the approach of block selective lithiation and modification can be used as a general strategy to prepare durable and functional nanostructured polymer membranes and materials.

\section{Acknowledgements}

The research leading to these results has received funding from the European Community's Seventh Framework Programme (FP7/2010-2013) under the call ENERGY-2010-10.2-1: Future Emerging Technologies for Energy Applications (FET) under contract 256821 QuasiDry. 


\section{References}

1 M. Banks, J. R. Ebdon and M. Johnson, Polymer, 1994, 35, 3470.

2 D. D. Jiang, Q. Yao, M. A. McKinney and C. A. Wilkie, Polym. Degrad. Stabil., 1999, 63, 423.

3 S. S. Azim, S. Sathiyanarayanan, G. Verikatachari, Progr. Org. Coat., 2006, 56, 154.

4 T. Anthierens, L. Billiet, F. Devlieghere, F. Du Prez, Innov. Food Sci. Emerg. Technol., 2012, 15, 81 .

5 J. Ellis, M. Anstice and A. D. Wilson, Clin. Mater., 1991, 7, 341.

6 G. O. Adusei, S. Deb and J. W. Nicholson, Dent. Mater., 2005, 21, 491.

7 N. Zhang, S. Salzinger, B. Rieger, Macromolecules, 2012, 45, 9751.

8 T. Bock, H. Möhwald and R. Mülhaupt, Macromol. Chem. Phys., 2007, 208, 1324.

9 B. Lafitte and P. Jannasch, On the prospects for phosphonated polymers as proton-exchange fuel cell membranes, in Advances in Fuel Cells, ed. T. S. Zhao, K. D. Kreuer and T. Van Nguyen, 2007, Elsevier, Oxford, vol. 1, pp. 119-185.

10 A. Rusanov, P. Kostoglodov, M. M. Abadie, V. Voytekunas and D. Likhachev, ProtonConducting Polymers and Membranes Carrying Phosphonic Acid Groups. In Fuel Cells II, Scherer, G., Ed. Springer Berlin Heidelberg: 2008; Vol. 216, pp 125-155.

11 R. Tayouo, G. David, B. Ameduri, Eur. Polym. J., 2010, 46, 1111.

12 R. Tayouo, G. David, B. Ameduri, J. Roziere, S. Roualdes, Macromolecules, 2010, 43, 5269.

13 B. J. Liu, G. P. Robertson, M. D. Guiver, Z. Q. Shi, T. Navessin, S. Holdcroft, Macromol. Rapid Commun., 2006, 27, 1411.

14 C. Stone, T. S. Daynard, L. Q. Hu, C. Mah, A. E. J. Steck, New Mater. Electrochem. Syst., $2000,3,43$.

15 S. V. Kotov, S. D. Pedersen, W. M. Qiu, Z. M. Qiu, D. J. Burton, J. Fluorine Chem., 1997, 82, 13 .

16 M. Yamabe, K. Akiyama, Y. Akatsuka, M. Kato, Eur. Polym. J., 2000, 36, 1035.

17 H. R. Allcock, M. A. Hofmann, C. M. Ambler, S. N. Lvov, X. Y. Y. Zhou, E. Chalkova, J. Weston, J. Membr. Sci., 2002, 201, 47. 
18 Y. Z. Meng, S. C. Tjong, A. S. Hay, S. J. Wang, Eur. Polym. J., 2003, 39, 627.

19 K. Miyatake, A. S. Hay, J. Polym. Sci., Pol. Chem., 2001, 39, 3770.

20 T. Rager, M. Schuster, H. Steininger, K. D. Kreuer, Adv. Mater., 2007, 19, 3317.

21 B. Lafitte, P. Jannasch, J. Polym. Sci., Pol. Chem., 2005, 43, 273.

22 J. Parvole, P. Jannasch, J. Mater. Chem., 2008, 18, 5547.

23 E. Abouzari-Lotf, H. Ghassemi, A. Shockravi, T. Zawodzinski, D. Schiraldi, Polymer, 2011, $\mathbf{5 2}, 4709$.

24 S. I. Lee, K. H. Yoon, M. Song, H. G. Peng, K. A. Page, C. L. Soles, D. Y. Yoon, Chem. Mater., 2012, 24, 115.

25 K. D. Papadimitriou, A. K. Andreopoulou, J. K. Kallitsis, J. Polym. Sci., Pol. Chem., 2010, 48, 2817.

26 H. Steininger, M. Schuster, K. D. Kreuer, A. Kaltbeitzel, B. Bingol, W. H. Meyer, S. Schauff, G. Brunklaus, J. Maier, H. W. Spiess, Phys. Chem. Chem. Phys., 2007, 9, 1764.

27 A. Kaltbeitzel, S. Schauff, H. Steininger, B. Bingol, G. Brunklaus, W. H. Meyer, H. W. Spiess, Solid State Ionics, 2007, 178, 469.

28 R. Perrin, M. Elomaa and P. Jannasch, Macromolecules, 2009, 42, 5146.

29 T. Wagner, A. Manhart, N. Deniz, A. Kaltbeitzel, M. Wagner, G. Brunklaus, W. H. Meyer, Macromol. Chem. Phys., 2009, 210, 1903. 
30 P. R. Sukumar, W. C. Wu, D. Markova, O. Unsal, M. Klapper, K. Mullen, Macromol. Chem. Phys., 2007, 208, 2258.

31 J. Parvole, P. Jannasch, Macromolecules, 2008, 41, 3893.

32 M. Ingratta, M. Elomaa, P. Jannasch, Polym. Chem., 2010, 1, 739.

33 R. W. Lindström, A. Oyarce, L. G. Aguinaga, D. Ubeda, M. Ingratta, P. Jannasch, G. Lindbergh, J. Electrochem. Soc., 2013, 160, F269.

34 G. J. Schlichting, J. L. Horan, J. D. Jessop, S. E. Nelson, S. Seifert, Y. Yang, A. M. Herring, Macromolecules, 2012, 45, 3874.

35 L. Gubler, D. Kramer, J. Belack, O. Unsal, T. J. Schmidt, G. G. Scherer, J. Electrochem. Soc., 2007, 154, B981.

36 F. Schoenberger, J. Kerres, J. Polym. Sci., Polym. Chem., 2007, 45, 5237.

37 K. Nakabayashi, T. Higashihara, M. Ueda, J. Polym. Sci., Polym. Chem., 2010, 48, 2757.

38 H. S. Lee, A. S. Badami, A. Roy, J. E. McGrath, J. Polym. Sci., Polym. Chem., 2007, 45, 4879 .

39 Y. Chen, C. H. Lee, J. R. Rowlett, J. E. McGrath, Polymer, 2012, 53, 3143.

40 S. Takamuku, P. Jannasch, Adv. Energy Mater., 2012, 2, 129.

41 N. Inagaki, K. Goto and K. Katsuura, Polymer, 1975, 16, 641.

42 Plastics Flamability Handbook: Pronciples Regulations, Testing, and Approval; J. Troitzsch, Ed.; Hanser Publishers: Munich, 1983; Chapter 5.1.2.2. 


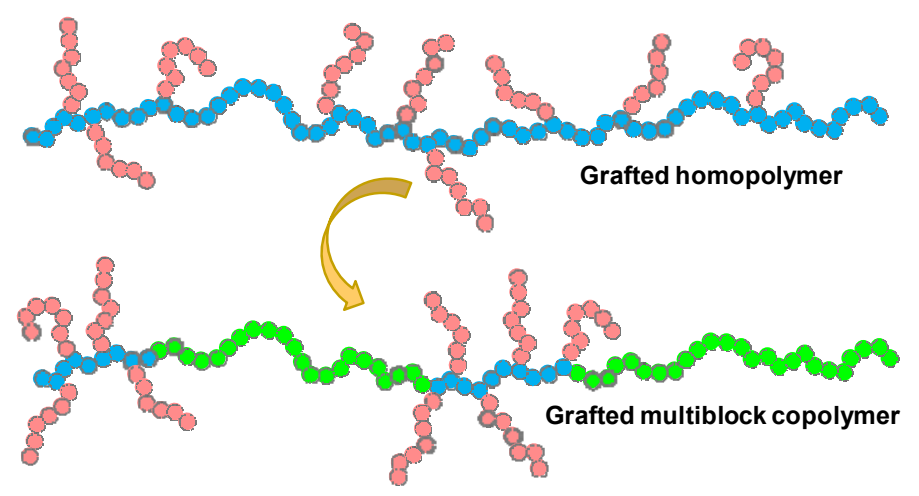

Scheme 1. Molecular structure of a grafted homopolymer (upper) and a selectively grafted multiblock copolymer (lower) containing PVPA (green), PSU (blue) and PFE (red) segments. 


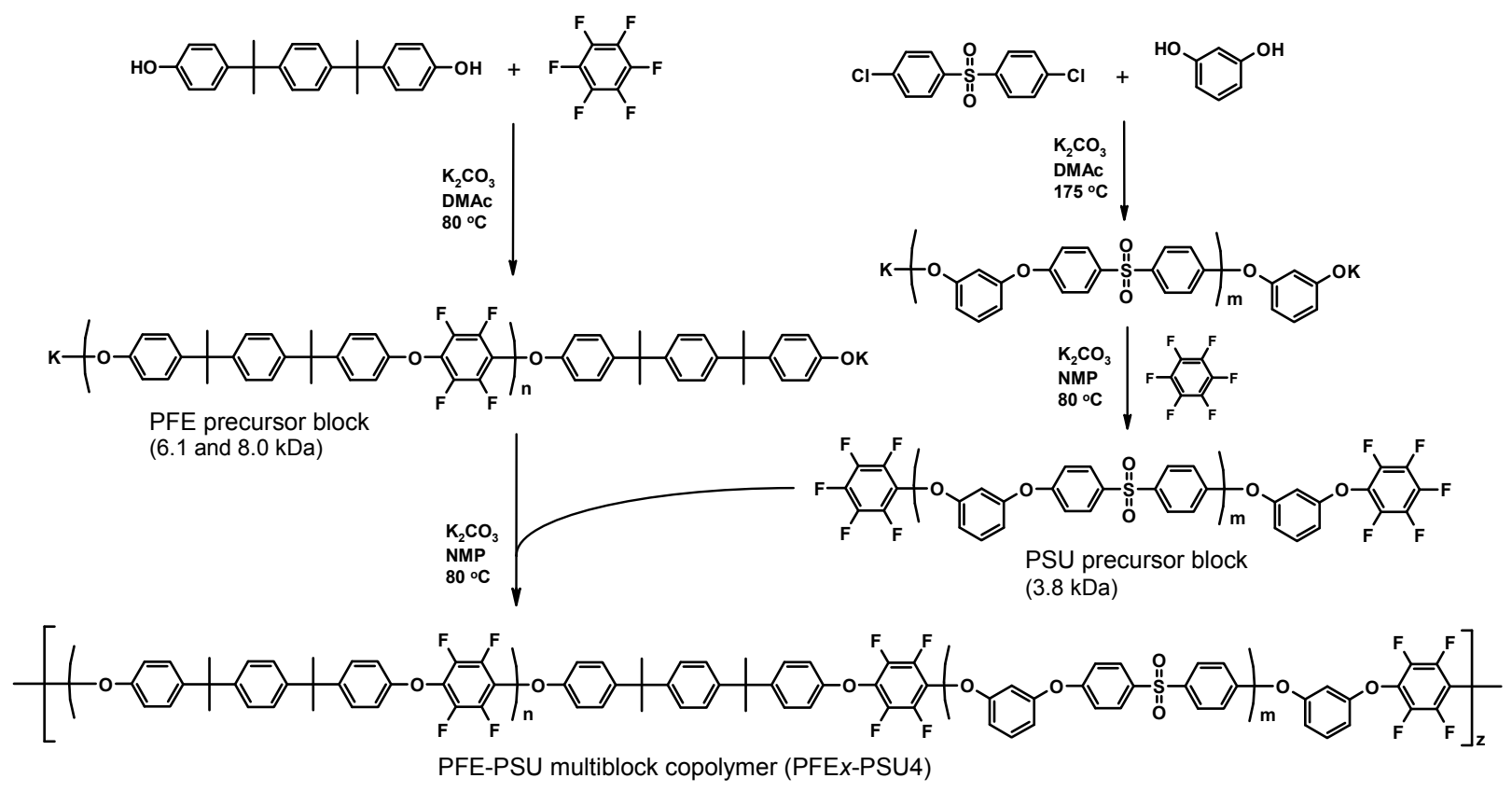

Scheme 2. Synthetic pathway to PFE-PSU multiblock copolymers via coupling reactions of hydroxy terminated PFE and pentafluorophenyl terminated PSU precursor blocks under mild conditions ( $x$ denotes the molecular weight of the PFE block in $\mathrm{kDa}$ ). 

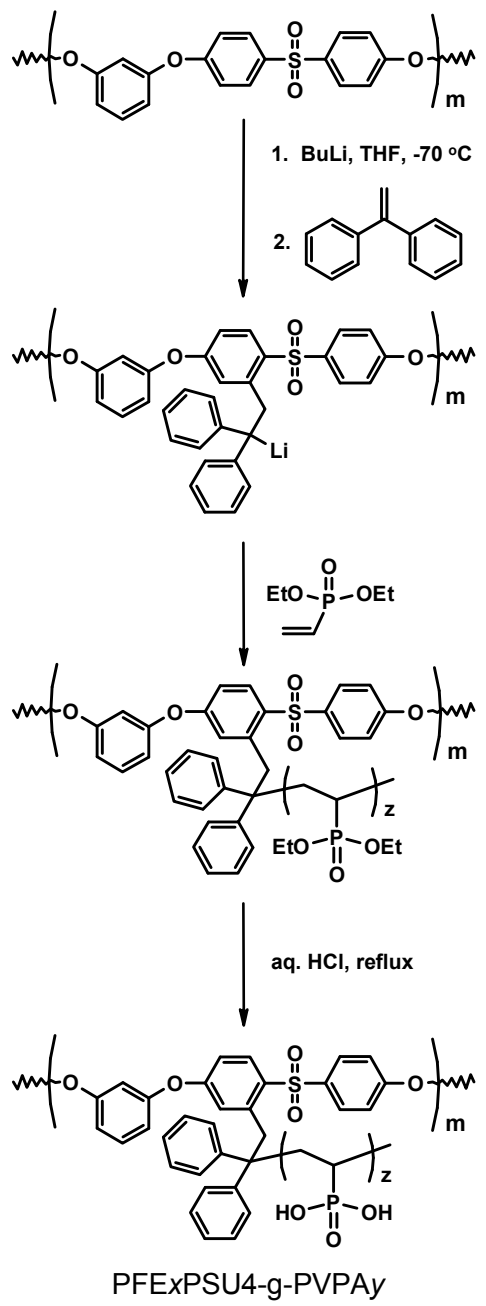

Scheme 3. Selective lithiation and grafting of the PSU blocks of the multiblock copolymers via anionic polymerization of DEVP, followed by cleavage of the ester functions to obtain the PVPA side chains ( $y$ denotes the PVPA content of the multiblock copolymer in wt $\%$ ) 


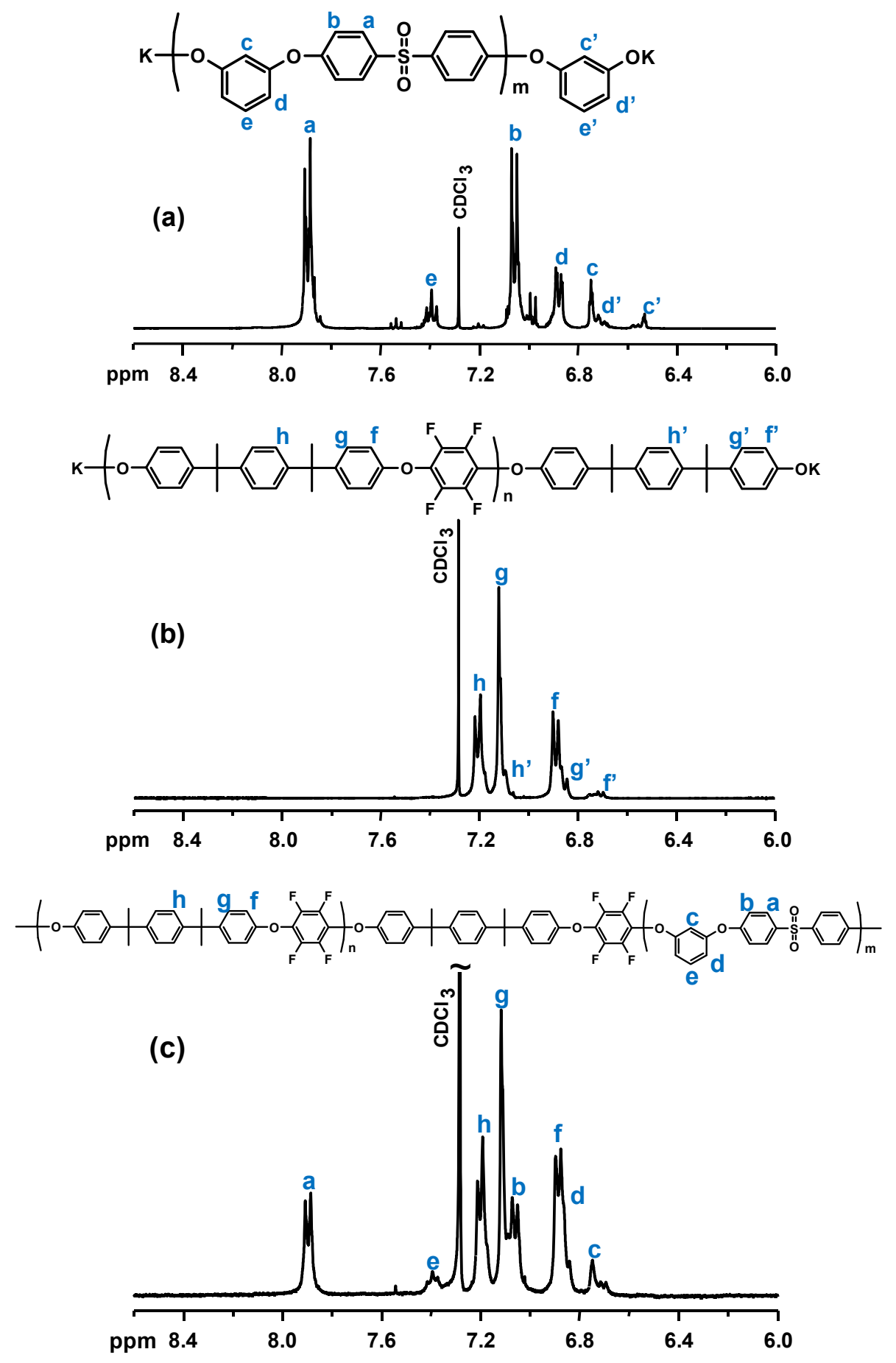

Fig. $1{ }^{1} \mathrm{H}$ NMR spectra of the PSU4 (a) and PFE8 (b) precursor blocks, as well as of multiblock copolymer PFE8PSU4 (c). All the spectra were recorded with polymers dissolved in $\mathrm{CDCl}_{3}$. 


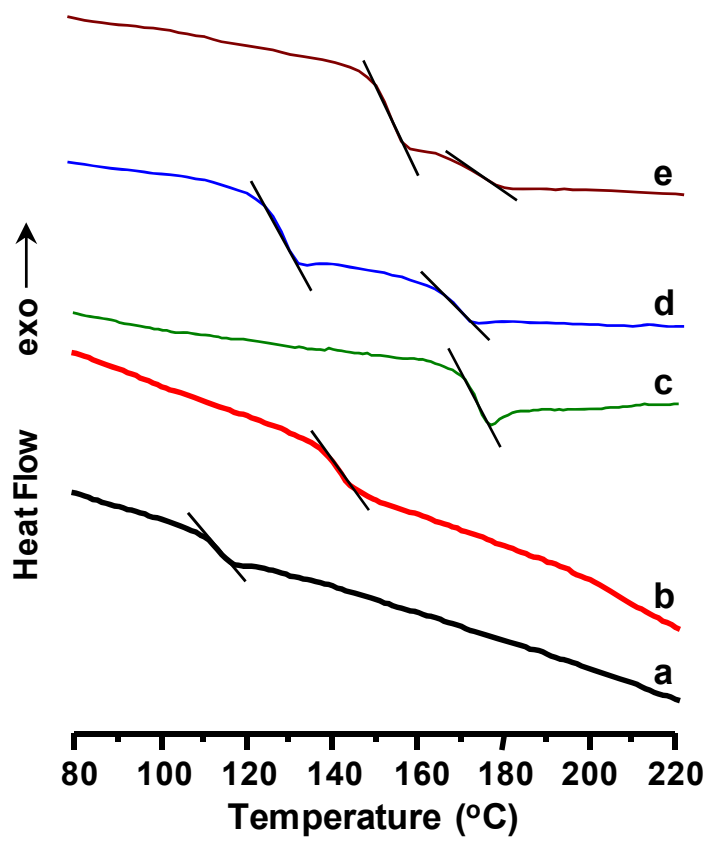

Fig. 2 DSC traces of precursor blocks PFE6 (a), PFE8 (b), and PSU4 (c), and multiblock copolymer PFE6PSU4 (d) and PFE8PSU4 (e). The multiblock copolymers show separate $T_{\mathrm{g}} \mathrm{s}$ $\left(T_{\mathrm{g} 1}\right.$ and $\left.T_{\mathrm{g} 2}\right)$ to indicate phase separation. Data was recorded during heating at $10{ }^{\circ} \mathrm{C} \mathrm{min}^{-1}$ and the glass transitions are indicated by thin lines. 

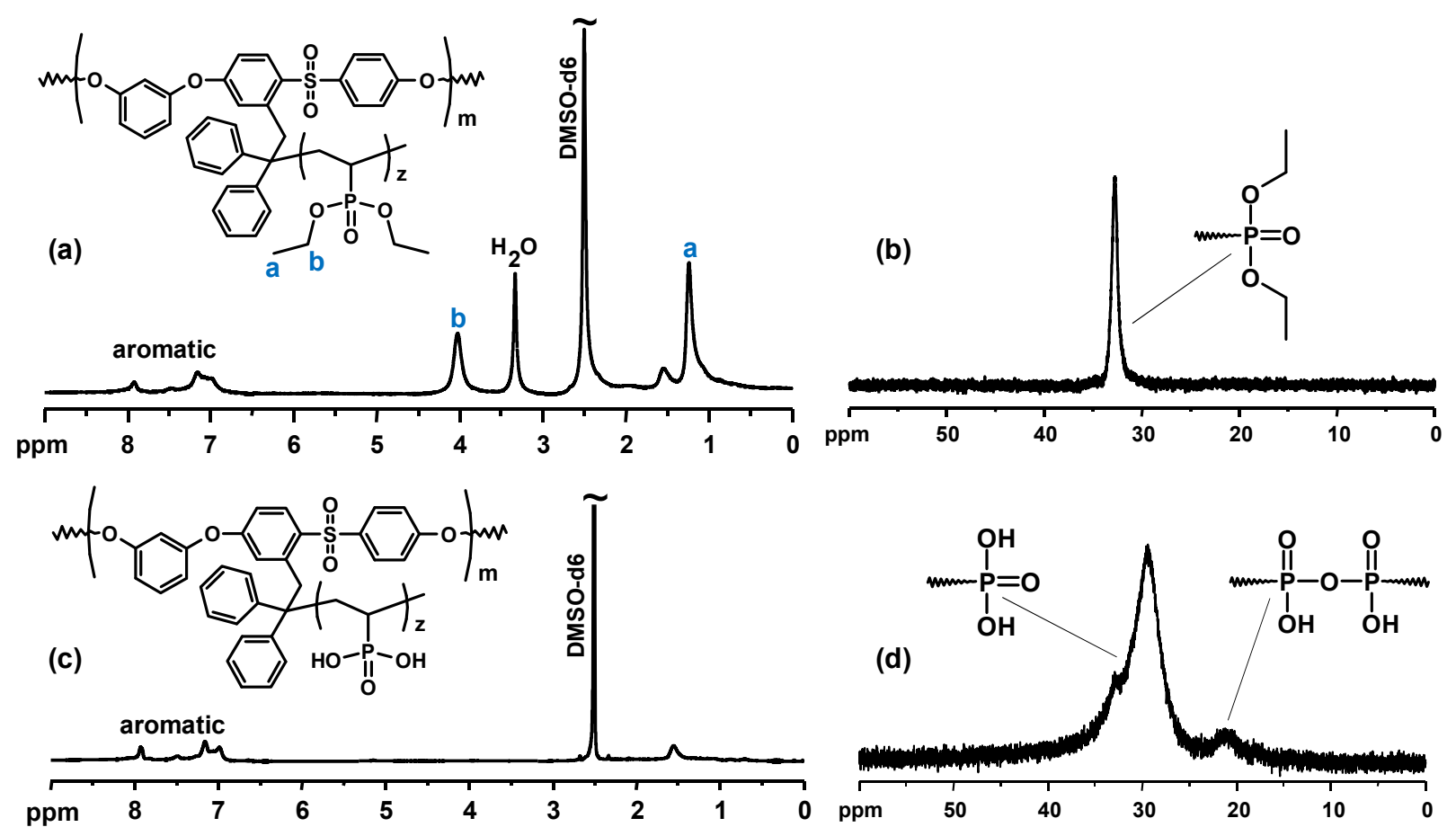

Fig. $3{ }^{1} \mathrm{H}$ NMR (left) and ${ }^{31} \mathrm{P}$ NMR (right) spectra of the grafted multiblock copolymer PFE8PSU4- $g$-PVPA59 carrying phosphonated side chains in the ester form $(a, b)$ and in the acid form (c, d), respectively. Data were collected using DMSO- $d_{6}$ solutions. 


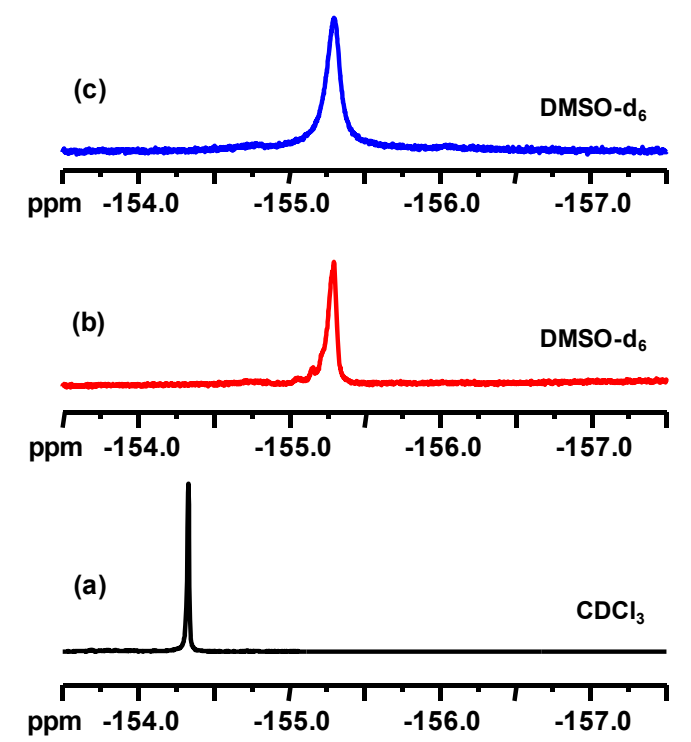

Fig. $4{ }^{19} \mathrm{~F}$ NMR spectra of multiblock copolymer PFE8PSU4 recorded in $\mathrm{CDCl}_{3}$ (a) and DMSO-d 6 (b), and of the grafted multiblock copolymer PFE8PSU4-g-PVPA82 in the ester form recorded in DMSO- $d_{6}$ (c). 


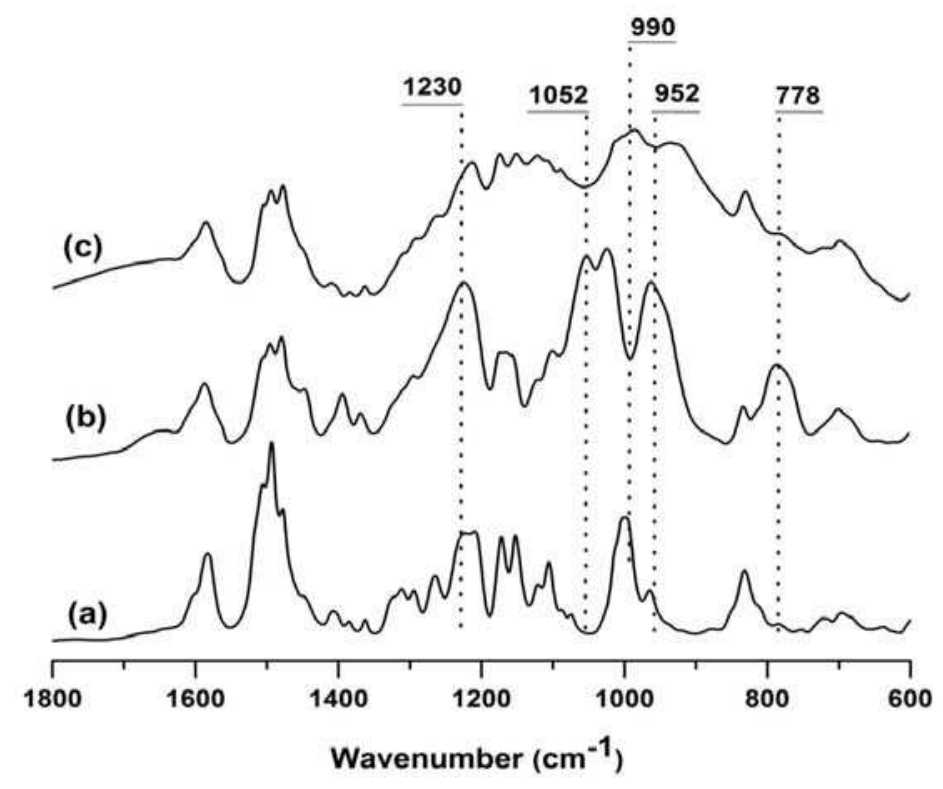

Fig. 5 FTIR spectra of multiblock copolymers PFE6PSU4 (a), and PFE6PSU4-g-PVPA68 in the ester (b) and acid (c) form. 

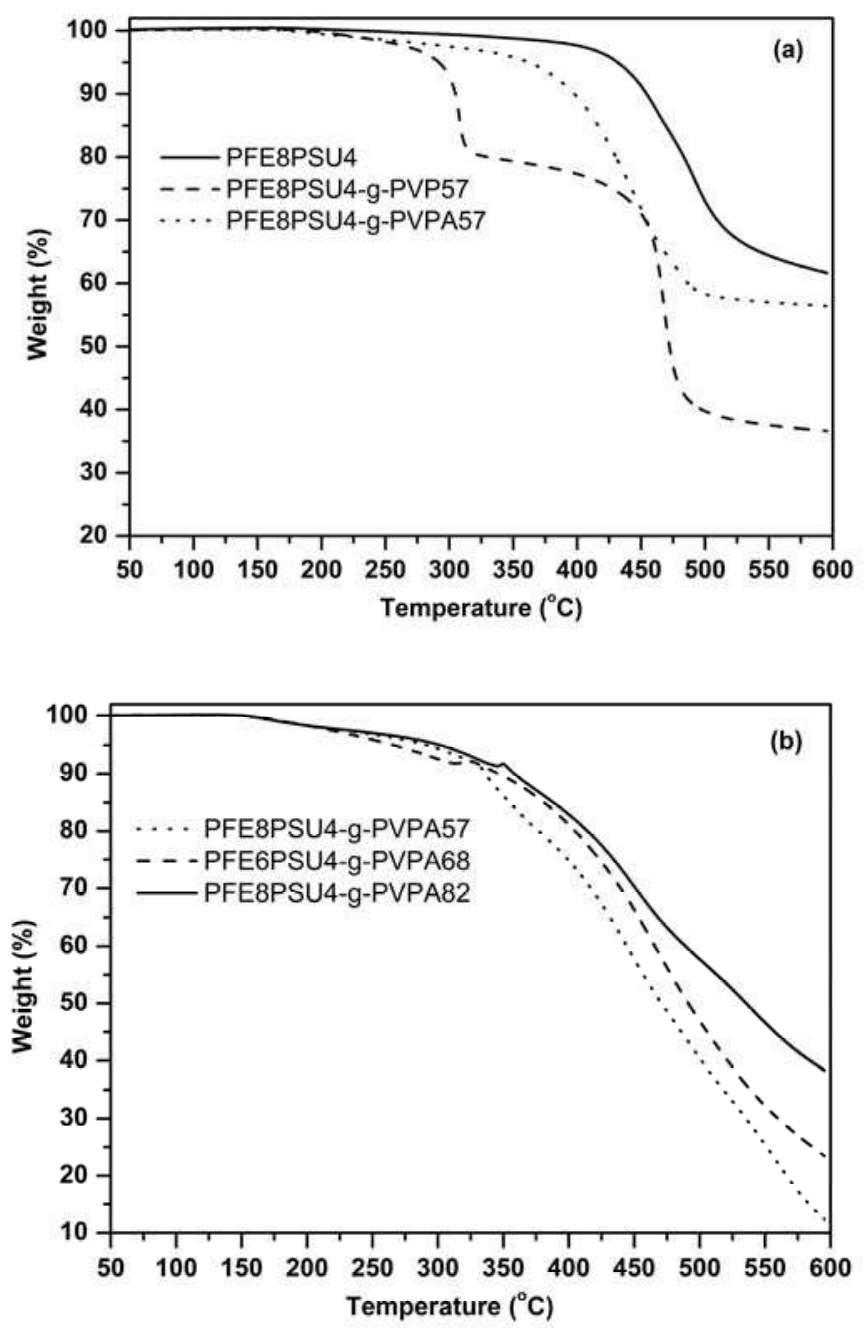

Fig. 6 TGA curves of (a) multiblock copolymers PFE8PSU4, PFE8PSU4-g-PVPA57 in the ester and acid form, respectively (recorded at $10{ }^{\circ} \mathrm{C} \mathrm{min}^{-1}$ under nitrogen), and (b) TGA curves of PFExPSU4- $g$ PVPAy samples in the acid form with PVPA contents ranging from 57 to $82 \mathrm{wt} \%$ (recorded at $1{ }^{\circ} \mathrm{C} \mathrm{min}^{-1}$ under air). 


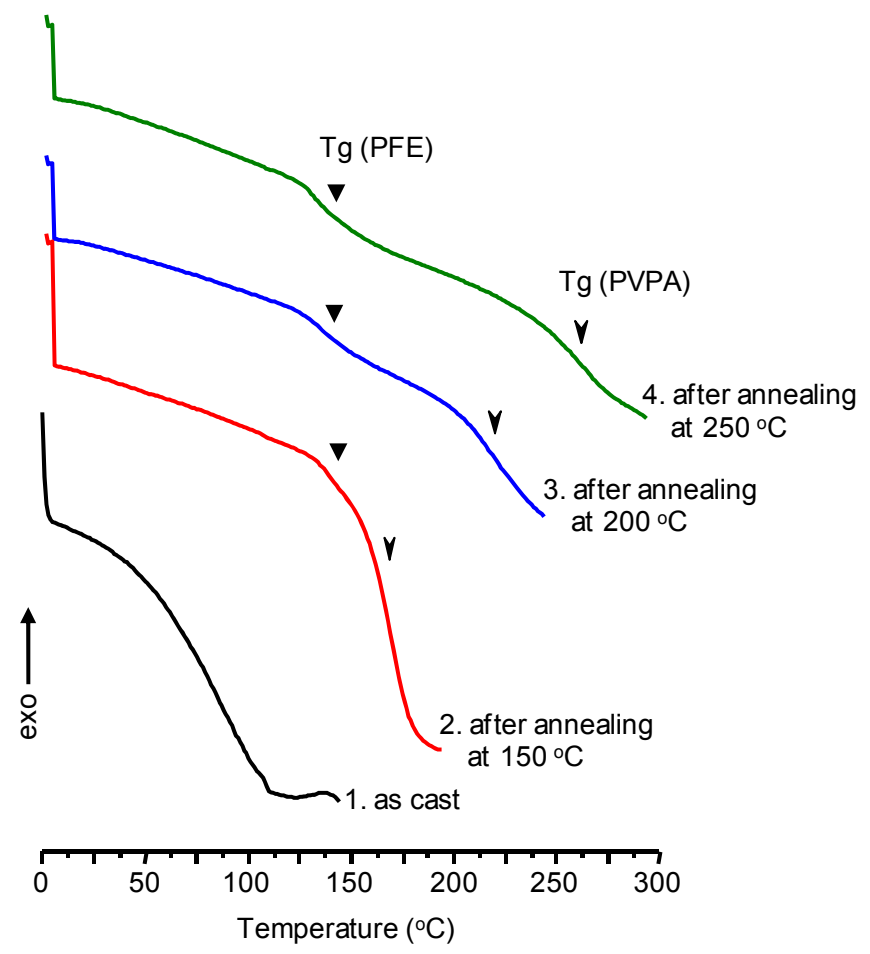

Fig. 7 DSC heating traces of grafted multiblock copolymer PFE8PSU4-g-PVPA59 showing the successively increasing $T_{\mathrm{g}}$ of the PVPA phase during the scan sequence: $0 \rightarrow 150 \rightarrow 0 \rightarrow 200 \rightarrow 0 \rightarrow$ $250 \rightarrow 0 \rightarrow 300{ }^{\circ} \mathrm{C}$ at $20{ }^{\circ} \mathrm{C} \mathrm{min}-1$. The $T_{\mathrm{g}}$ of the PFE phase remains constant at approx. $150{ }^{\circ} \mathrm{C}\left(T_{\mathrm{g}} \mathrm{s}\right.$ indicated by arrowheads). 


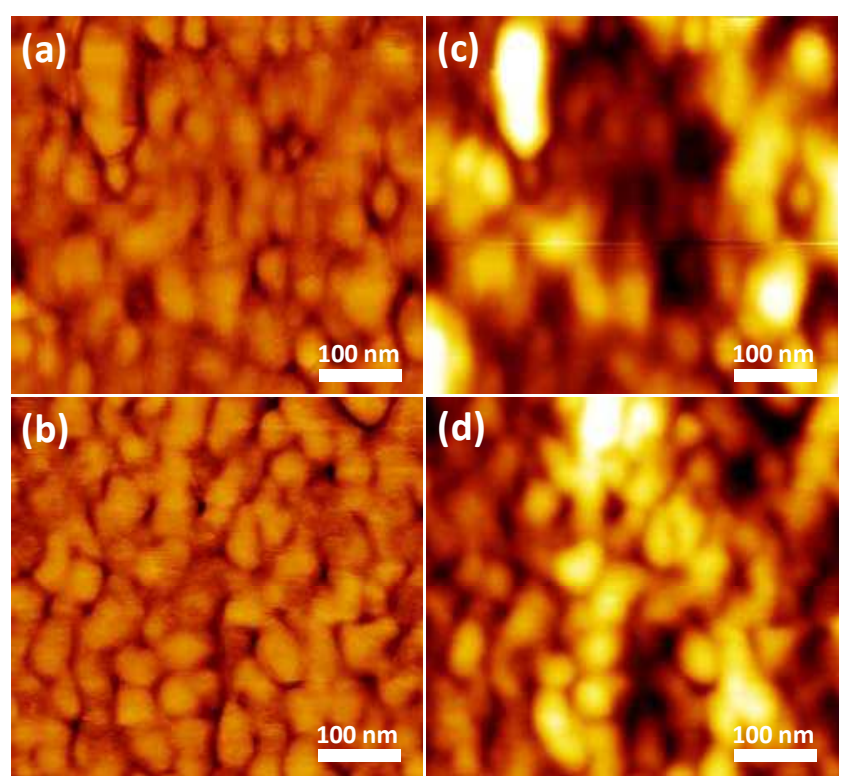

Fig. 8 Tapping mode AFM phase images of PFE8PSU4-g-PVPA57 (a) and PFE8PSU4-g-PVPA82 (b) surfaces, respectively. The hard PFE and soft PVPA phases appear as bright and dark areas, respectively. The corresponding topography images are shown in part $\mathrm{c}$ and $\mathrm{d}$, respectively. 

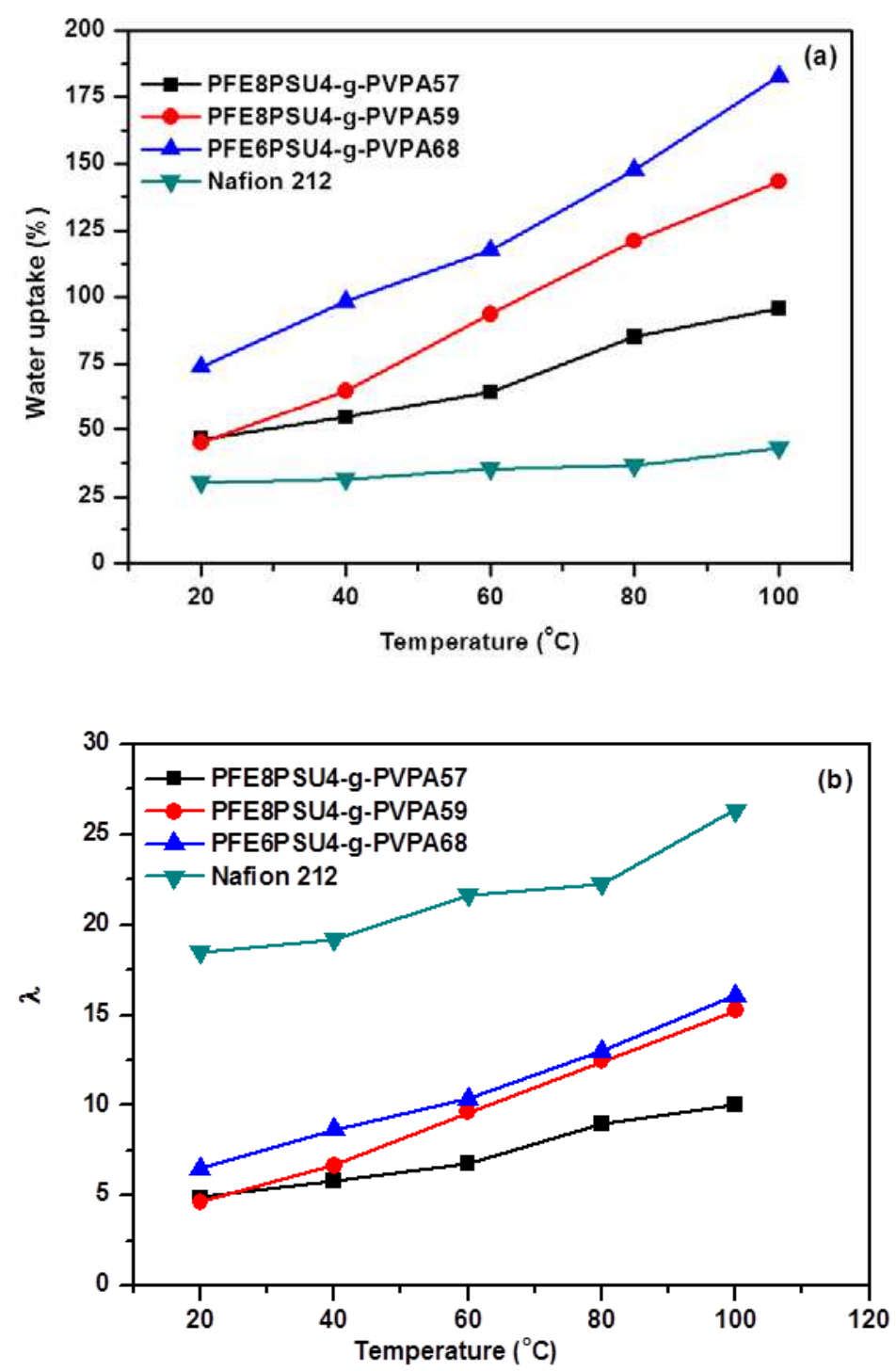

Fig. 9 The water uptake (a) and $\lambda$ (b) for the phosphonated multiblock copolymer membranes as a function of temperature under immersed conditions. The data of Nafion ${ }^{\circledR}$ NRE212 was added for reference. 


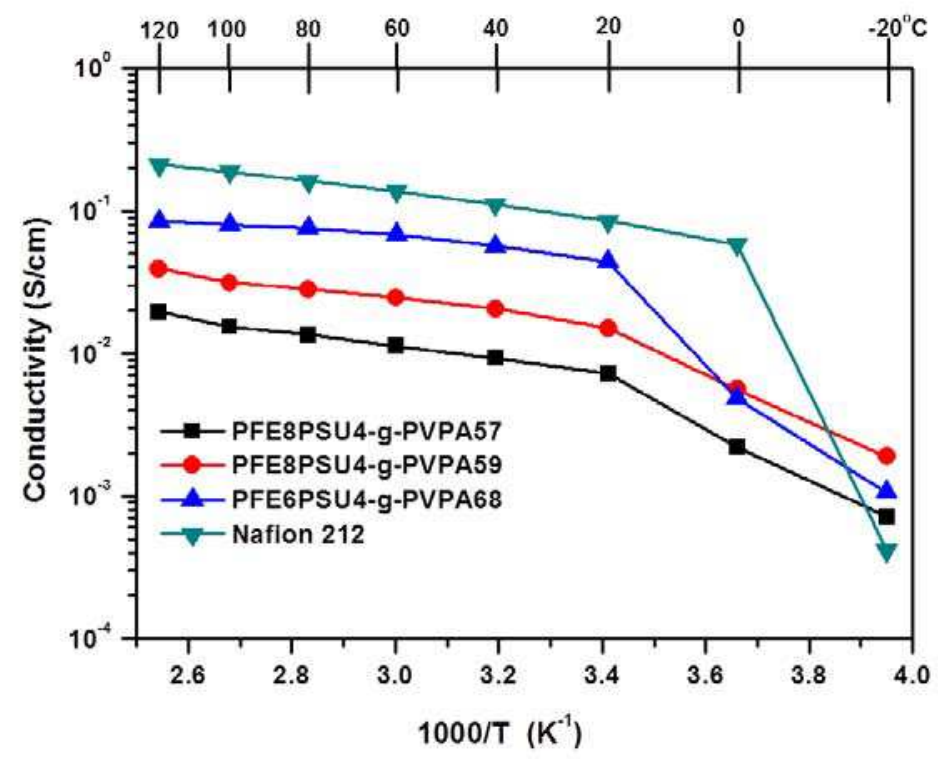

Fig. 10 Proton conductivity data measured under fully hydrated conditions for the phosphonated multiblock copolymer membranes using EIS. The data of Nafion ${ }^{\circledR}$ NRE212 was added for reference. 
Table 1. Multiblock copolymer data.

\begin{tabular}{|c|c|c|c|c|c|c|c|}
\hline \multirow[b]{2}{*}{$\begin{array}{l}\text { Multiblock } \\
\text { copolymer }\end{array}$} & \multirow[b]{2}{*}{$\begin{array}{c}\text { PFE precursor } \\
\text { block MW } \\
(\mathrm{kDa})\end{array}$} & \multirow[b]{2}{*}{$\begin{array}{l}\text { PSU precursor } \\
\text { block } \mathrm{MW}^{\mathrm{a}} \\
(\mathrm{kDa})\end{array}$} & \multirow{2}{*}{$\begin{array}{c}\text { PFE } \\
\text { precursor } \\
\text { block } T_{\mathrm{g}}{ }^{\mathrm{b}} \\
\left({ }^{\circ} \mathrm{C}\right)\end{array}$} & \multirow{2}{*}{$\begin{array}{c}\text { PSU } \\
\text { precursor } \\
\text { block } T_{\mathrm{g}}{ }^{\mathrm{b}} \\
\left({ }^{\circ} \mathrm{C}\right)\end{array}$} & \multicolumn{3}{|c|}{ PFExPSU4 copolymer } \\
\hline & & & & & $\begin{array}{l}T_{\mathrm{g} 1}^{\mathrm{b}} \\
\left({ }^{\mathrm{o}} \mathrm{C}\right)\end{array}$ & $\begin{array}{l}T_{\mathrm{g} 2}^{\mathrm{b}} \\
\left({ }^{\mathrm{o}} \mathrm{C}\right)\end{array}$ & $\begin{array}{l}T_{d}{ }^{\mathrm{c}} \\
\left({ }^{\mathrm{o}} \mathrm{C}\right)\end{array}$ \\
\hline PFE6PSU4 & $6.1(5.0)$ & $3.8(5.7)$ & 115 & 174 & 128 & 171 & 465 \\
\hline PFE8PSU4 & $8.0(8.2)$ & $3.8(5.7)$ & 143 & 174 & 153 & 176 & 456 \\
\hline
\end{tabular}

${ }^{\mathrm{a}}$ Molecular weight calculated from NMR data and values in parenthesis calculated from SEC data using polystyrene standards. ${ }^{b}$ Determined by DSC. ${ }^{\mathrm{c}}$ Temperature for $5 \%$ weight loss at $10{ }^{\circ} \mathrm{C} \mathrm{min}{ }^{-1}$ under $\mathrm{N}_{2}$.

Table 2. Grafted multiblock copolymer data.

\begin{tabular}{|c|c|c|c|c|c|c|}
\hline \multirow{2}{*}{$\begin{array}{c}\text { Grafted } \\
\text { multiblock } \\
\text { copolymer }\end{array}$} & \multirow{2}{*}{$\begin{array}{l}\text { Precursor } \\
\text { multiblock } \\
\text { copolymer }\end{array}$} & \multirow{2}{*}{$\begin{array}{c}\text { Ratios of the } \\
\text { reactants } \\
\text { DEP:DEVP:PSU } \\
\text { (mmol) }\end{array}$} & \multicolumn{2}{|c|}{ DEVP content (wt\%) } & \multirow{2}{*}{$\begin{array}{l}\text { PVPA } \\
\text { content } \\
(\mathrm{wt} \%)\end{array}$} & \multirow{2}{*}{$\begin{array}{c}\mathrm{IEC}^{\mathrm{b}} \\
\left(\mathrm{mmol}^{\mathrm{P}}\right. \\
\left.\mathrm{g}^{-1}\right)\end{array}$} \\
\hline & & & $\begin{array}{c}\text { by } \\
{ }^{1} \mathrm{H} \text { NMR }\end{array}$ & $\begin{array}{c}\text { by } \\
\text { TGA }^{\text {a }}\end{array}$ & & \\
\hline PFE6PSU4-g-PVPA68 & PFE6PSU4 & $0.23: 4.6: 0.47$ & 76 & 74 & 68 & 6.3 \\
\hline PFE6PSU4-g-PVPA75 & PFE6PSU4 & $0.23: 8.8: 0.47$ & 82 & 83 & 75 & 6.9 \\
\hline PFE8PSU4-g-PVPA57 & PFE8PSU4 & $0.23: 2.0: 0.46$ & 66 & 52 & 57 & 5.2 \\
\hline PFE8PSU4- $g$-PVPA59 & PFE8PSU4 & $0.23: 2.2: 0.46$ & 68 & 47 & 59 & 5.4 \\
\hline PFE8PSU4- $g$-PVPA82 & PFE8PSU4 & $0.23: 9.0: 0.46$ & 88 & 84 & 82 & 7.7 \\
\hline
\end{tabular}

${ }^{a}$ Determined via the weight loss at $350{ }^{\circ} \mathrm{C}$ recorded by TGA under nitrogen. ${ }^{b}$ Calculated from ${ }^{1} \mathrm{H}$ NMR data. 
Table 3. Grafted multiblock copolymer membrane properties.

\begin{tabular}{c|c|c|c|c|c|c}
\hline Copolymer & $\begin{array}{c}\text { PVPA } \\
\text { content } \\
(\mathrm{wt} \%)\end{array}$ & $\begin{array}{c}T_{\mathrm{d}}{ }^{\mathrm{a}} \\
\left({ }^{\circ} \mathrm{C}\right)\end{array}$ & $\begin{array}{c}\mathrm{IEC}^{\mathrm{b}} \\
\left(\mathrm{mmol} \mathrm{P} \mathrm{g}^{-1}\right)\end{array}$ & $\begin{array}{c}W_{\text {water }}{ }^{\mathrm{c}} \\
(\mathrm{wt} \%)\end{array}$ & $\lambda_{20}{ }^{\mathrm{o}} \mathrm{C}^{\mathrm{d}}$ & $\begin{array}{c}\sigma^{\mathrm{e}} \\
\left(\mathrm{mS} \mathrm{cm}^{-1}\right)\end{array}$ \\
\hline PFE6PSU4-g-PVPA68 & 68 & 264 & 6.3 & 74 & 6.5 & 85 \\
PFE6PSU4-g-PVPA75 & 75 & 246 & 6.9 & - & - & - \\
PFE8PSU4-g-PVPA57 & 57 & 332 & 5.2 & 46 & 4.8 & 20 \\
PFE8PSU4-g-PVPA59 & 59 & 292 & 5.4 & 45 & 4.7 & 39 \\
PFE8PSU4-g-PVPA82 & 82 & 310 & 7.7 & - & - & - \\
\hline
\end{tabular}

a Temperature for $5 \%$ weight loss under air at $1{ }^{\circ} \mathrm{C} \mathrm{min}{ }^{-1} ;{ }^{b}$ Calculated from ${ }^{1} \mathrm{H}$ NMR data; ${ }^{\mathrm{c}}$ Determined at $20{ }^{\circ} \mathrm{C}$ under immersed conditions; ${ }^{d}$ Number of absorbed water molecules per phosphonic acid group at $20{ }^{\circ} \mathrm{C}$; ${ }^{\mathrm{e}}$ Measured under immersed conditions at $120^{\circ} \mathrm{C}$. 